\title{
Bile acids as colon carcinogens and coffee ingredients as antagonists
}

\author{
H. M. Bolt $\cdot$ R. Marchan $\cdot$ J. G. Hengstler
}

Published online: 24 July 2011

(C) Springer-Verlag 2011

High dietary fat is associated with increased colon cancer risk. A possible mechanism is that dietary fat stimulates hepatocytes to secrete bile acids into bile canaliculi which are necessary for solubilization and absorption of lipids in the gut (Hewitt et al. 2007; Hoehme et al. 2010; Hofmann 1999a, b; Modica et al. 2008). Bile acids have been reported to act as tumor promoters in the colon (Degirolamo et al. 2011; Gadaleta et al. 2010; Modica et al. 2008), most probably via generation of reactive oxygen species, a mechanism of central interest for our journal (Bhusari et al. 2010; Bolt and Hengstler 2010; Degirolamo et al. 2011; Kawai et al. 2010; Kell 2010; Kumar and Gill 2009; Michalowicz 2010). The editors are happy that Carol Bernstein and colleagues from the University of Arizona contributed a study that gives additional insight into the role of bile acids as colon carcinogens (Bernstein et al. 2011; this issue). They demonstrated that deoxycholic acid at high physiological levels induced colon carcinomas in mice. Addition of the antioxidative compound, chlorogenic acid to the diet clearly reduced tumor induction by deoxycholic acid, which is present at relatively high concentrations in coffee. Importantly, Bernstein et al. controlled the concentration of deoxycholic acid in feces of their mice by mass spectrometry and compared it to the human situation. Concentrations in the exposed mice were $4.6 \mathrm{mg}$ deoxycholic acid/g dry feces compared to only $0.3 \mathrm{mg} / \mathrm{g}$ in control mice. In humans, deoxycholic acid concentrations range between 2.3 and $4.1 \mathrm{mg} / \mathrm{g}$ dry feces for non-controlled diets and may increase to $6.4 \mathrm{mg} / \mathrm{g}$ for high fat diets. Therefore, the data of

H. M. Bolt · R. Marchan $(\bowtie) \cdot$ J. G. Hengstler Leibniz Institut für Arbeitsforschung an der TU Dortmund, Leibniz Research Centre for Working Environment and Human Factors (IfADo), Ardeystrasse 67, 44139 Dortmund, Germany e-mail: marchan@ifado.de
Bernstein and colleagues demonstrate that deoxycholic acid may contribute to human colon carcinogenesis.

\section{References}

Bernstein C, Holubec H, Bhattacharyya AK, Nguyen H, Payne CM, Zaitlin B, Bernstein H (2011) Carcinogenicity of deoxycholate, a secondary bile acid. Arch Toxicol 85 [Epub ahead of print]

Bhusari S, Abouraya M, Padilla ML, Pinkerton ME, Drescher NJ, Sacco JC, Trepanier LA (2010) Combined ascorbate and glutathione deficiency leads to decreased cytochrome $b_{5}$ expression and impaired reduction of sulfamethoxazole hydroxylamine. Arch Toxicol 84:597-607

Bolt HM, Hengstler JG (2010) Oxidative stress and hepatic carcinogenesis: new insights and applications. Arch Toxicol 84:87-88

Degirolamo C, Modica S, Palasciano G, Moschetta A (2011) Bile acids and colon cancer: solving the puzzle with nuclear receptors. Trends Mol Med [Epub ahead of print]

Gadaleta RM, van Mil SW, Oldenburg B, Siersema PD, Klomp LW, van Erpecum KJ (2010) Bile acids and their nuclear receptor FXR: relevance for hepatobiliary and gastrointestinal disease. Biochim Biophys Acta 1801:683-692 (Review)

Hewitt NJ, Lechón MJ, Houston JB, Hallifax D, Brown HS, Maurel P, Kenna JG, Gustavsson L, Lohmann C, Skonberg C, Guillouzo A, Tuschl G, Li AP, LeCluyse E, Groothuis GM, Hengstler JG (2007) Primary hepatocytes: current understanding of the regulation of metabolic enzymes and transporter proteins, and pharmaceutical practice for the use of hepatocytes in metabolism, enzyme induction, transporter, clearance, and hepatotoxicity studies. Drug Metab Rev 39:159-234

Hoehme S, Brulport M, Bauer A, Bedawy E, Schormann W, Hermes M, Puppe V, Gebhardt R, Zellmer S, Schwarz M, Bockamp E, Timmel T, Hengstler JG, Drasdo D (2010) Prediction and validation of cell alignment along microvessels as order principle to restore tissue architecture in liver regeneration. Proc Natl Acad Sci USA 107: 10371-10376

Hofmann AF (1999a) The continuing importance of bile acids in liver and intestinal disease. Arch Intern Med 159:2647-2658

Hofmann AF (1999b) Bile Acids: the good, the bad, and the ugly. News Physiol Sci 14:24-29 
Kawai M, Saegusa Y, Dewa Y, Nishimura J, Kemmochi S, Harada T, Ishii Y, Umemura T, Shibutani M, Mitsumori K (2010) Elevation of cell proliferation via generation of reactive oxygen species by piperonyl butoxide contributes to its liver tumor-promoting effects in mice. Arch Toxicol 84:155-164

Kell DB (2010) Towards a unifying, systems biology understanding of large-scale cellular death and destruction caused by poorly liganded iron: Parkinson's, Huntington's, Alzheimer's, prions, bactericides, chemical toxicology and others as examples. Arch Toxicol 84:825-889 (Review)
Kumar V, Gill KD (2009) Aluminium neurotoxicity: neurobehavioural and oxidative aspects. Arch Toxicol 83:965-978

Michałowicz J (2010) Pentachlorophenol and its derivatives induce oxidative damage and morphological changes in human lymphocytes (in vitro). Arch Toxicol 84:379-387

Modica S, Murzilli S, Salvatore L, Schmidt DR, Moschetta A (2008) Nuclear bile acid receptor FXR protects against intestinal tumorigenesis. Cancer Res 68:9589-9594 